レーザー画像血流計の開発と応用

山本有平, 大浦武彦，杉原平樹，小野一郎，松本敏明，皆川英彦，井川浩晴， 野平久仁彦, 浅見謙二**, 藤居 仁 ${ }^{* * *}$

北海道大学医学部形成外科, ${ }^{*}$ 日鋼記念病院, ${ }^{* *}$ 旭川厚生病院,

****九州工業大学電子情報工学科

索引用語； レーザー血流計，画像血流計，サーモグラフィー，血管腫，皮弁

\title{
Development and Application of the Laserflowgraphy
}

Yuhe i Yamamoto, M.D., Takehiko Ohura, M.D., Tuneki Sugihara, M.D., Ichi ro Ono, M.D., Toshiaki Matsumoto, M.D., Hidehiko Minakawa, M.D., Hiroharu Ikawa, M.D. Kunihiko Nohira, M.D., Kenji Azami , M.D.* and Hi toshi Fuji i, Ph.D.

Department of Plastic and Reconstructive Surgery, Faculty of Medicine, University of Hokkaido, Sapporo 060

* Nikko Memorial Hospital, Muroran 051, *Asahikawa Kosei Hospital, Asahikawa 078 , Department of Computer Science and Electronics, Kyushu Institute of Technology, Iizuka 820

\section{ABSTRACT}

The laserflowgraphy, was developed to visualize the skin blood flow, has been applied to measure the microcirculation in various angiopathy, avasculized skin and several types of skin $f$ laps. These laserflowgrams were evaluated, and some of them were compared with the thermograms.

The thermograms were under the influence of deeply influent arteries, on the other hand the laserf lowgrams reflected the cumulative microvascular blood flow to the depth of the papillary dermis of the skin.

It was noted that the microvascvlar circulation of the skin is displayed as the mottled pattern, is variably distributed, which was never found by means of the conventional laser flow meters that can measure the blood flow of only one spot in the observation area at one time.

This laserflowgraphy can measure the skin blood flow noninvasively, quickly and sequentialy at any place, so it is very useful and practical.

Key words; Laser Flow Meter, Laserflowgraphy, Thermography Hemangioma, Flap

\section{緒 言}

われわれは、てれまでレーザースペックル現象を利用 して、皮閣血流の二次元分布図である血流マップを求め、 それをカラーグラフィックに表示できるレーザー画像血

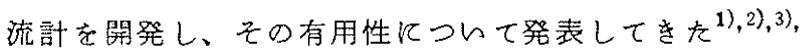
4),5) 今回はてれまて本血流計を用いて測定してきた形 成外科領域飞晾叮血管腫、閉塞性動脈硬化症、flap のモニタ一をとの臨床例、および駆血飞ょる皮展血流の 変化、flap の血流動態の実験例などついて、一部サ 一モグラフィーと比較対照し交がらその結果を報告し、 現在まで本レーザ一画像血流計を使用してをた経験をる とに本血流計の特性について検討を加える。

\section{測定対象および結果}

本レーザー画像血流計を用いて測定してき臨床例な らびに実験例について供覽する。以後、本レーザー画像
血流計で得られを画像をレーザーフローグラムと呼ぶ。 な就此詨照したサーモグラムは日本電気三栄株式会社 のサーモトレーサ 6 T 62 を用的測定した。

1. 单純性血管腫：浅在型（Superficially located type）では血管腫領域の皮咸血流壮高值を示すが、深 在型（Deeply located type）で恃皮阔表首の血流牥古 まり高くない ${ }^{6)}$ (図 1 )。

2. 勘静脈奇形（左小指）：隣接する正常な環指、中 指に比へ明ら加波阔血流恃低々。しかし動静脈奇形て 岋梁部の血管は発達し、シャントが生じ皮下血流量は多 く、サーモグラムでは高温域として表示される(図2)。

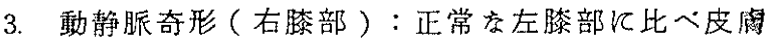

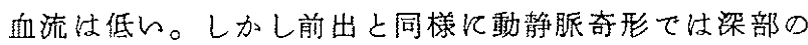
血流は高いのて、サーモグラムでは高温域として表示さ れる(図3)。

4. 閉塞性動脈硬化症飞生した難治性潰绶(左内果部) : 溃婸底部不良組織の租流仕低いが、肉芽が生している

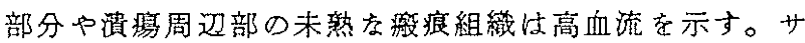


ーモグラムでは後脛骨動脈が皮下の浅いとてろを走行す る部位に一致して高温域になっている（図４）。

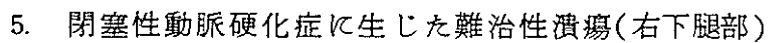
: 前出之同様儿蛽瘍底部不良組織の血流山低く、肉芽中

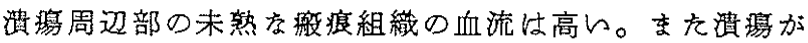
生してない部分の血流す正常人に比へると低い。サーも グラムでは蛽筇部を中心に著しい低温域になっている。 溃婸の左下方にのびている低温域は皮下に生じた細長い 死腔部分と一致している(図 5 )。

6. 歌血状態の指尖：正常人の示指をネラトンカテー テルで5分間媻血し測定した。示指末節部の血流は低く 古っている(図6)。

7. 各纴下の㪙血状態の前腕 : 血王 $100 / 80 \mathrm{mmHg}$ の 正常人の上䑨部をェアートニッケットを用い 50,100 , $200 \mathrm{mmHg}$ の王て 5 分間媐血し、前腕部の血流状態を剆 定した。血流の低下は一様でなく，場所に上り差異が見 られ、最高血圧以上の圧で駆血すると血流は汪とんどみ られ交くな（図７）。

8. random pattern flap delay: 肉眼でややうっ 血している左側のf1apが明らかに低ら血流值を示す（図 $8)$ 。

9. 家鬼の耳介に作製した axial pattern flapとra一 ndom pattern flap： 本血流計で flap の血流動態の経 時的変化を測定した。術直後より axial pattern flap で沽年介中心聂静脈が走るflap 正中部より辺縁部へ血流 值の勾配がみられ、 random pattern flapではflapの proximal sideよりdistal side八の血流值の勾配が られ、術後 6 時間にはその勾配は非常飞明らかになる (図 9 )。

考案

われわれが新しく開発したレーザー画像血流計はレー ザースペックル現象を利用するととにより皮睢の乳頭下 層あをりまての毛細血管内の赤血球の動をを直接捉える ことができるとと、観測野の血流分布を二次元的にカラ ーグラフィックに表示できるとと、生体侵謷を加えず に短時間でかつ連続的に測定が行えるとと、なとの特幑 を有してんる ${ }^{4)}$ 。

皮㬝は均一な組織ではな、レーザーの逶過性が一定

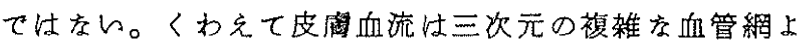
り構成されていて、レーザースベックル現象を用いた皮

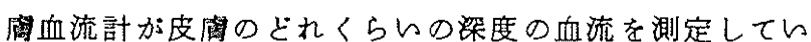
るのかについては現在す颔問が残されている。われわれ

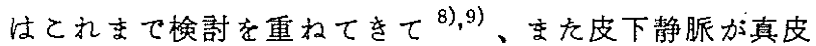

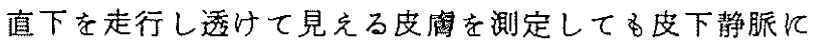
一致した高血流域は得られないといったよらな経験的な てとから、本血流計では皮蚠表層上り真皮の浅い首つま り乳頭下層亦をり亲での血流の累積值を測定表示してい

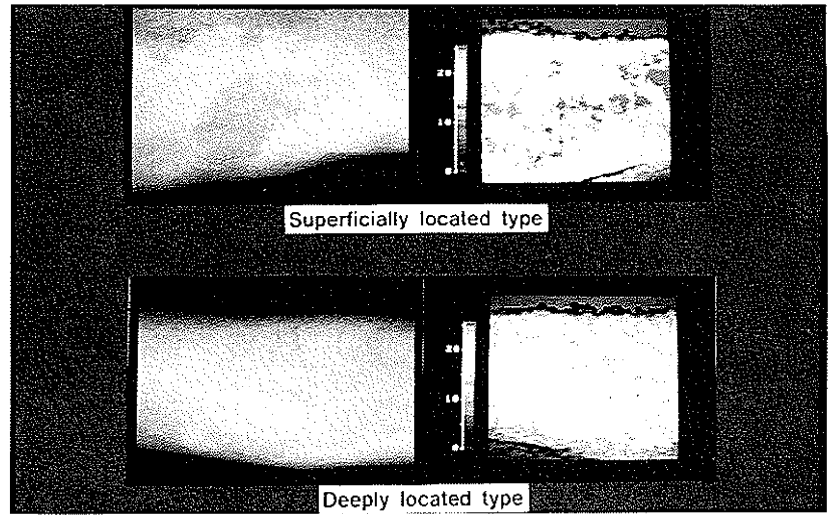

図 1 单純性血管腫の臨床例（左）とLaserflowgram（右）。 Superficially located type（上）の皮虚表殿血流は高いが、 Deeply located type（下）の皮䖉表層血流はあまり高くない。

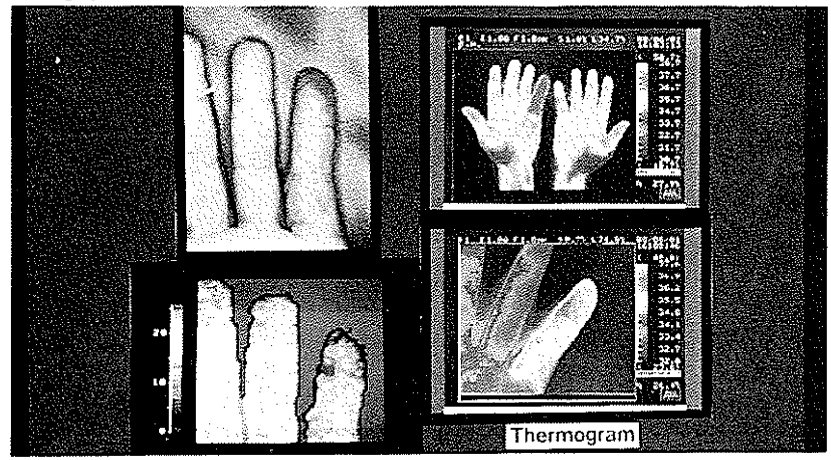

図2 動静脈奇形（左小指）の臨床例（左上）Laserflowgram (左下)、Thermogram (右)。小指の皮履血流は低いが、

Thermogramでは高温域に示される。

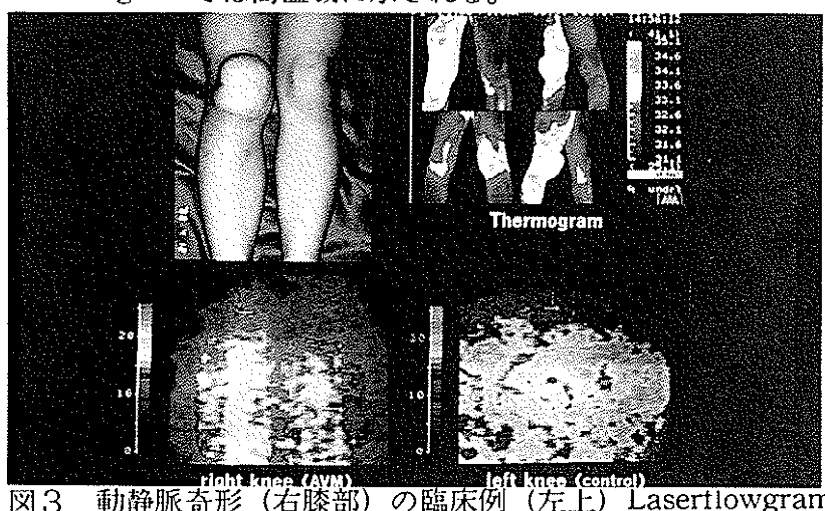
図3 動静脈奇形 (右滕部) の臨床例 (左上) Lasertlowgran

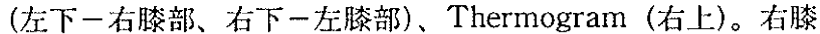
部の皮䖉血流は低いが、Thermogramでは高温域に示される。

るものと考えている。今回の血管腫の症例でる、血管腫 組織が主として真皮上層に分布する浅在型ては高血流を 示し、梁在型では血流值はすまり高く表示されない。動 静脈奇形の症例です、サーモグラムでは流入動脈域に一 致して高温域が示されているが、本血流計ては皮固血流 は低く示され、深部血流飞影缺されない。閉塞性動脈硬 化症沈いてすサーモグラムては動脈が皮下の浅い層を 走行している部位壮高温域として示されるのに対し、本 血流計で肉䒧部分や未熟な搬痕組蟣の部分が高血流域 として表示され、表在血流を反映している。こらした今 回の測定結果は本血流計が、皮咸表層のおそらくは真皮 乳頭下首あたりまての血流状態をきわ忠実に反映し 


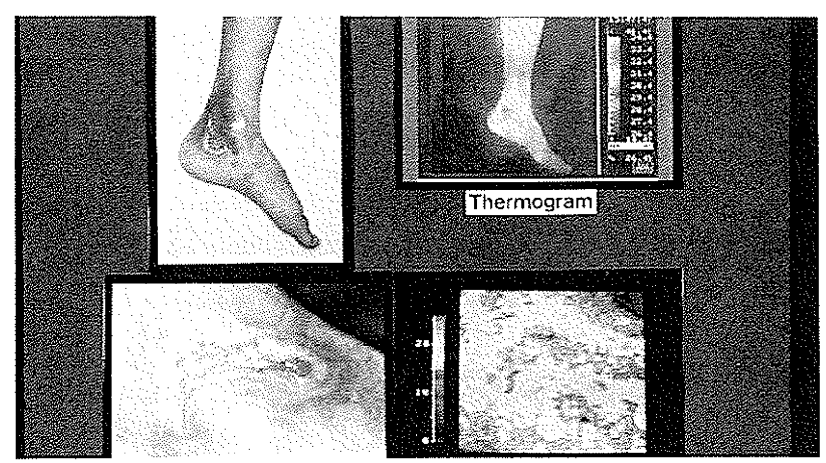

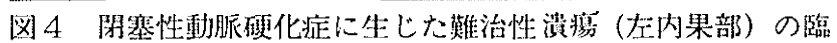
床例 (左)、Laserflowgram (右下)、Thermogram (在上)。

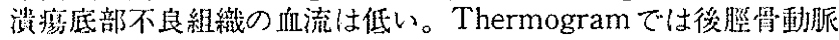
の部位に一致して高温域になっている。

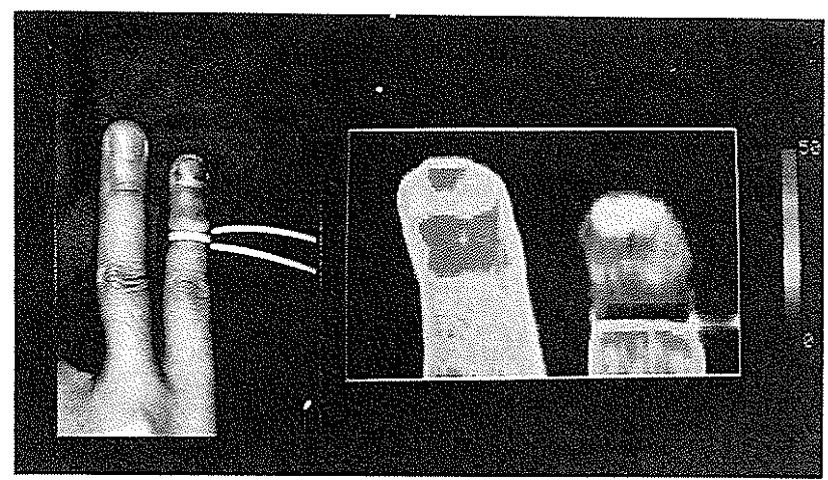

区6 駆血状態の指尖の臨床例（左）、Laserflowgram（右）。 示指末節部は低血流を示す。

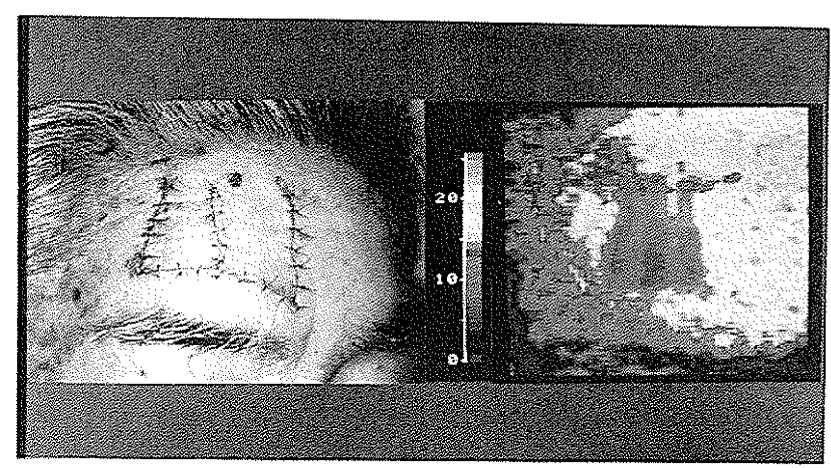

図 8 random pattern flapを delayした臨休例 (左)、

Laserflowgram（右）。うつ血している左側の flapの血流が低 t.

ているととを示するのである。本血流計は末梢循環動態 を二次元的にカラー画像として表示でるるがーモグ ラフィーと比較されるが、サーモグラフィーは皮成表面 上り放射される赤外エネルギーを湘定する琹置であり、 それは深部の流入動脈に影製されており、本血流計とは 全〈別のすので今回の測定結果が明確に物語っている。

本血流計で正常人の皮觕を測定すると、血流マップは まを模様水なり、皮府血流の分布が一定でないととが 判明し、従来のレーザースペックル血流計である一点の みを測定した場合、皮凰血流の值に壮らつをが存在した 原因が解明された。そして今回の駆血の実験で流入血流

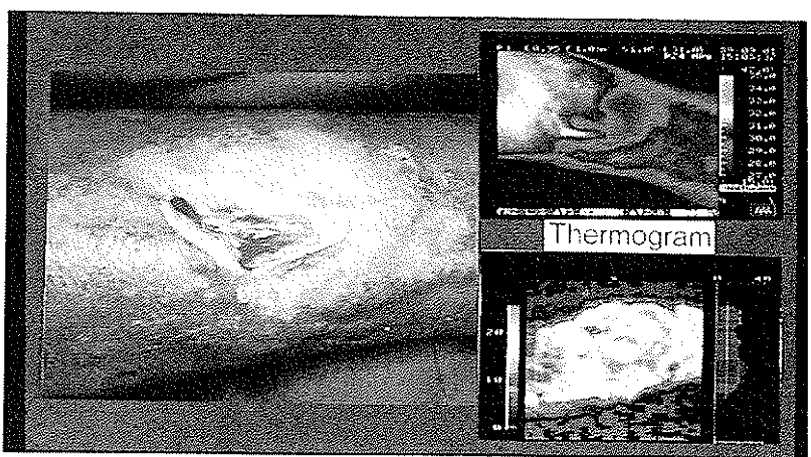

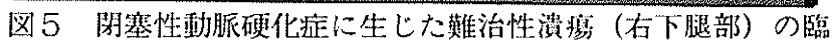
床例 (左)、Laserflowgram (右下)、Thermogram (右上)。

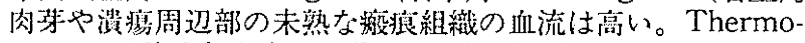
gramでは濒境部を中心に著しい低温域になっている。

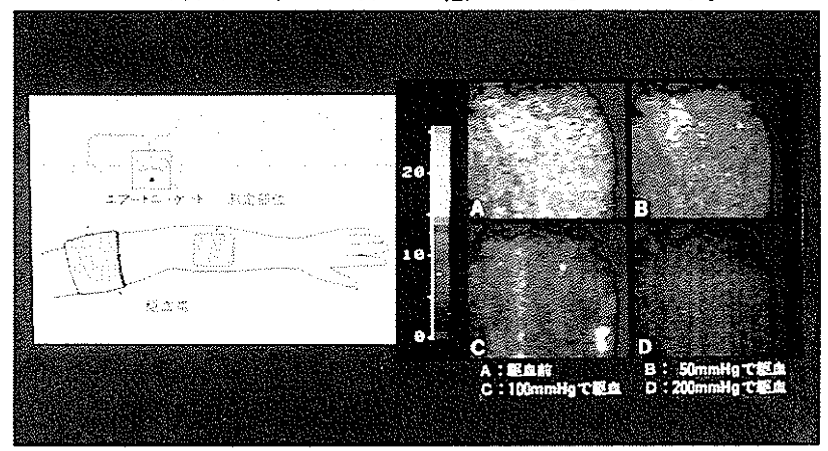

図7 上腕部をエアートニッケットを用い50,100,200 $\mathrm{mmHg}$ の圧で5分間駆血した（上）際の前腕部の Laserflowgram (下)。 駆血压により血流の低下は一㥞でなく場所により差異が見られ

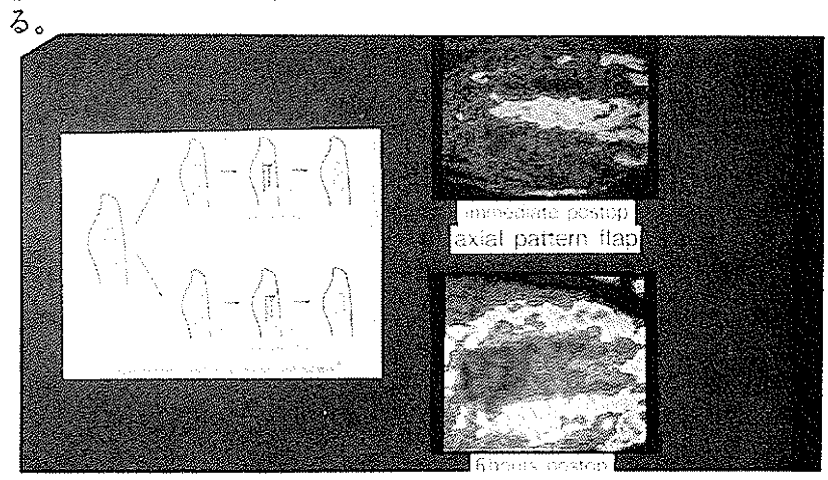

四9 家息の耳介にaxial pattern flap と random pattern flap 作慜し (左)、flapの血流動態の経時的变化を测定した。 flap 正中部より辺緣部へ䖝流值の勾配がみられる axial pattern flapの Laserflowgram (右上)。flap $の$ proximal sideより distal sideへの血流值の勾配がみられる random pattern flapの Laserflowgram (右下)。

が減少した場合、皮蔺血流の分布変化が一様てはなく場 所に上り差があるととるわかった。また動物実験で flap を挙上した際、axial pattern flap $と$ random pattern flapでは異なる血流值の勾配が生しるととも判明した。 こらした所見は、本血流計が観測野の血流分布の二次元 表示を可能にしてはしめて得られたすのて、一点のみを 測定する機能しかるたない今までのレーザー血流計では 測り知れなかったととである。

皮虚血流を測定する方法は数多くあ百加、その中で現 在最信頼されているるのに ${ }^{133} \mathrm{Xe}$ クリアランス法があ

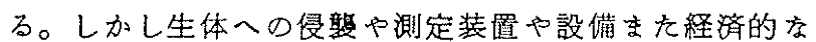


問題から、容易にベッドサイドで皮咸血流を測定すると いう上ら交実用性に汒乏しい。との点、本レーザー画像 血流計性体に無侵缶に短時間でかつ連続的にどてでで も測定ができ、皮風表層の血流動態を明確に把握でき非 常に有用である。

てれからは皮閣だけでなく、本血流計をマイクロ化 し内視鏡に装着するととにょって、気道や消化管の粘膜 の血流状㮩の測定す可能飞なると思われ、また眼底検查

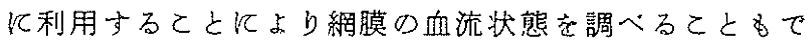

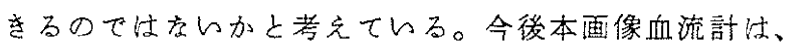

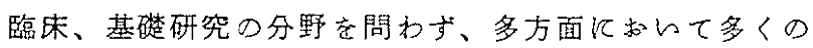
有用存情報を提供するととが期待でる。

\section{結 語}

1) 本レーザー画像血流計を用らて測定した臨休例なら びに実験例を供覧した。

2) 本レーザー画像血流計とサーモグラフィーを血管病 変例を测定し比較検討した。その結果サーモグラフィー が樑部流入動脈の血流を反映しているのに対し、本血流

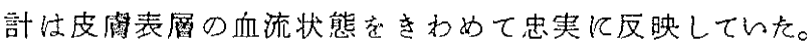

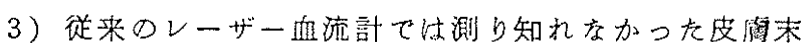
梢循環動態の二次元分布、かよびその变化が本血流計で 得られた血流マップにより判明した。

4) 本レーザー画像血流計は生体に無侵襲に短時間でか つ連続的によ゙てででる測定が可能でり実用性に富んて いる。

\section{参考文献}

1. H. Fujii, K. Nohira, Y. Yamamoto, et al. : Evaluation of Blood Flow by Laser Speckle Image Sensing. Part 1, Appl. Opt., 26: 53215325,1987

2.山本有平, 野平久仁彦, 大浦武彦, 保か：レーザー スペックル法による末梢循環来の画像化 (II)，日 本レーザー医学会誌，8（３）：169-170,1987

3. 藤居仁, 山本有平, 野平久仁彦, 供か：レーザ一 スペックル法に上る末梢循環采の画像化（Ｉ），日 本レーザ一医学会誌，8（4）：37-38,1988

4. 山本有平, 野平久仁彦, 大浦武彦, 活か：レーザー スペックル法による末梢循環采の画像化, 日本レー ザ一医学会誌, 9(1)：9-13,1988

5. 藤居仁, 山本有平, 野平久仁彦, 㴗か：レーザ一 スペックル法に上る末梢循環系の画像化（III），日 本レーザー医学会誌，9（3）：135-138, 1988
6. 松本敏明：単純性血管腫に対するアルコンンーザー 治撩の適応之限界, 形成外科，31（11）：9921004,1988

7.山本有平, 大浦武彦, 野平久仁彦, 任か：Flapの 血流動態の経時的変動につんて一末梢循環画像血流 計に上る検討一，日本レーザ一医学会誌，9（3）: $507-509,1988$

8. 藤居 仁, 原田康浩, 朝倉利光, 任か：レーザース ペックル現象を用いた皮碑血流测定（VII），日本レ ーザー医学会誌，7（3）：105-106，1987

9. 小野一郎, 大浦武彦, 山本有平, 你か：レーザース ペックル血流計の性能飞関する基礎的検討とこれを 用的有茎皮弁刀予後判定, 形成外科, $32(2)$ : $137-145,1989$ 